10.2478/aucft-2021-0001

\title{
ESSENTIAL OIL OF CYMBOPOGON CITRATUS GROWN IN UMUAHIA: A VIABLE CANDIDATE FOR ANTI-INFLAMMATORY AND ANTIOXIDANT THERAPY
}

\author{
- Research paper -
}

\section{Uchechi Bliss ONYEDIKACHI ${ }^{*}$, Favour Matthew AWAH*, Charles Nnanna CHUKWU*, Emmanuel EJIOFOR**}

\author{
*Department of Biochemistry, College of Natural Science, Michael Okpara University of \\ Agriculture Umudike, Nigeria. \\ **Department of Chemical Sciences, Faculty of Sciences, Clifford University, Owerrinta, Abia \\ State, Nigeria.
}

\begin{abstract}
The essential oils of Cymbopogon citratus (EOCC) has found use in medicine, food and chemical industry. This study attempts to provide evidence of its suitability for antioxidant and anti-inflammatory therapy. Total phenol and total flavonoid of EOCC was $49.83 \pm 0.39 \mathrm{mg} \mathrm{GAE} / \mathrm{g}$ of extract and $352.82 \pm 3.45 \mu \mathrm{g} \mathrm{QEC} / \mathrm{g}$ of extract respectively. Gas chromatography-mass spectrometry (GC-MS) analysis of its essential oil (EOCC) showed 25 peaks with myrcenyl acetate $(9.703 \%)$, caryophyllene $(8.997 \%)$, citronella $(6.383 \%)$ been the most abundant. The in vitro anti-inflammatory assay using human red blood cell (HRBC) membrane stabilization shows that at $200 \mu \mathrm{g} / \mathrm{mL}$, the percentage inhibition of EOCC was significantly higher compared to diclofenac both for heat-induced and hypotonic induced haemolysis. 2,2-diphenyl-1-picrylhydrazyl (DPPH) and ferric reducing antioxidant power (FRAP) assays showed a comparable and dose-dependent increase from 50 to $400 \mu \mathrm{g} / \mathrm{mL}$ in relation to vitamin C. Half maximal inhibitory concentration $\left(\mathrm{IC}_{50}\right)$ of EOCC $(73.16 \pm 12.89 \mu \mathrm{g} / \mathrm{mL}$ and $656.01 \pm 0.01 \mu \mathrm{mol} \mathrm{Fe}(\mathrm{II}) / \mathrm{L}$ ) was remarkably higher compared to that of vitamin $\mathrm{C}(69.09 \pm 4.52 \mu \mathrm{g} / \mathrm{mL}$ and $246.79 \pm 0.01 \mu \mathrm{mol} \mathrm{Fe}$ (II)/L) both for DPPH and FRAP assays respectively. In conclusion, results from this study establish preliminary evidence on the therapeutic potential of EOCC in managing inflammation and oxidative stress caused by free radicals.
\end{abstract}

Keywords: Antioxidant, Anti-inflammatory, Essential oils, Cymbopogon citratus.

\section{INTRODUCTION}

Medicinal plants are increasingly playing vital roles in the treatment and prevention of diseases in several parts of the world, including Nigeria (Chukwuma et al., 2015). Medicinal plants have been extensively used in folktale medicine because of their ethnopharmacological application (Idm'hand et al., 2019; Samoisy \& Mahomoodally, 2015), and they play vital roles in primary and public health care (Oladeji et al., 2019). Although most of these plants have been neglected in the past due to insufficient research on their essential oils and phytochemical constituent, increasing side effects resulting from the use of synthetic drugs and improvements in biotechnological methods (Fierascu et al., 2020; Olorunnisola et al. 2014; Tzanova et al., 2020; Wang \& Weller, 2006) has resulted in a bourgeoning interest to isolate and

Received: 12.02.2021

Accepted in revised form: 30.04 .2021 characterize the bioactive constituents of ethnopharmaceutical plants (Carson \& Hammer 2015; Dai \& Mumper, 2010; Ganjewala, 2009; González-Rodríguez, 2020; Sasidharan, 2011). These bioactive phytochemicals confer medicinal value to ethnopharmaceutical plants (Batubara et al., 2015; Misiak \& Lodyga-Chruscinska, 2010). Important and widely studied bioactive plants chemicals include flavonoids, phenolics, tannins, saponins and many more (Dai \& Mumper, 2010; Misiak \& Lodyga-Chruscinska, 2011; Gilling et al., 2014).

Cymbopogon citratus (C. citratus) is an aromatic perennial grass traditionally used as tea or decoction (Olorunnisola et al. 2014). Their extensive use is attributable to their nice taste and therapeutic potentials. C. citratus is identified by different names because of its wide distribution; however, it is commonly recognized as lemongrass or citronella. Nche awula (Igbo), Eti (Edo), ikon eti (Efik), Tsauri (Hausa), Myoyaka makara (Ibibio), and Koriko- oba (Yoruba) are local Nigerian

${ }^{1}$ Corresponding author. E-Mail address: ucheonyedi@gmail.com, ub.onyedikachi@mouau.edu.ng 
names for C. citratus (Aiyeloja \& Bello, 2006). Citronella, citronelle, squinant, citrongrass, gandhabene, xiang mao are the common names for $C$. citratus in the US, French-speaking countries, England, Sweden, India and China, respectively (Oladeji et al., 2019) Major attraction for researchers and local users are its rich composition of essential oil. Research findings have shown that the essential oil of $C$. citratus (EOCC) has high levels of geraniol, myrcene, citral (mixture of geranial and terpenoids), citronellol and $\alpha$-oxo-bisabolene (Ranitha, 2014).

Isolated forms of these compounds serve as important raw materials in the manufacturing industry for the production of several consumer products (Avoseh et al., 2015). For example, the lemon-like aroma and volatility of $C$. citratus derivatives such as citronella, makes its extracts useful in the manufacture of several consumer products such as deodorants, cosmetics, toiletries, aftershave, fragrances, perfume, local soaps, candle, insect repellents and culinary flavour (Garg et al., 2012; Oladeji et al., 2020). Also, people in Africa and Asia use C. citratus as a repellant for reptiles and, it has played a pivotal role in primary health care in these regions (Zhang et al., 2015; Lawal et al., 2017).

Previous studies have shown the in vivo antiinflammatory potentials of Cymbopogon citratus (e.g. Boukhatem et al., 2014; Garcia et al., 2015); the anti-nociceptive action (Quintans-Junior et al. 2011) and in vitro immunomodulatory effects of citral one of its major constituent (Bachiega \& Sforcin, 2011). These studies have shown that the leaves of $C$. citratus contain important phytotherapeutic compounds that confer the antioxidant, anti-inflammatory, (Unuigbe et al., 2019), anxiolytic (Costa et al., 2011), anti-fungi, anti-bacteria, anti-mutagenicity, anti-obesity (Olorunnisola et al., 2014), anti-malaria (Chukwuocha et al., 2016) properties of the plant. Also, several reviews on $C$. citratus discuss its anti-algesic, anti-hermetic, antispasmodic, antidyspeptic, anti-fever effects, antiseptic, antipyretic, tranquillizing, and diuretic potentials (Ademuyiwa et al., 2015; Oladeji et al., 2020).

An essential oil (EO) is usually a heterogeneous mix of plant secondary metabolites (20-100) with low molar mass (usually <500 Da) and belonging to very different chemical groups, for example, phenylpropanoids, terpenoids and their oxygenated derivatives (Carson \& Hammer, 2011). They are commonly isolated by solvent extraction, hydro distillation and steam distillation for commercialscale production. Usually, one or two bioactive compounds confers the biological activity to the essential oil mixture (Bakkali et al., 2008); however, in certain instances, the main bioactivities of the EO is not attributable to a single chemical constituent. Thus the synergic effect of several bioactive compounds confers the known chemical activity of the EO (Gulcin et al., 2016).

Both normal and pathological cellular processes result in the release of free radicals. For example, oxygen-derived free radicals are produced during normal cellular oxidation. Also, exogenous chemicals may trigger oxidative stress resulting in the release of more free radicals. Oxygen derived free radicals act by triggering oxidative processes, which may bring about cell death, tissue damage (Carson \& Hammer, 2015); and may start off disease progression, including arteriosclerosis, cancer, cirrhosis, rheumatoid arthritis and several other age-related health challenges (Nagavani et al., 2014).

However, oxidative enzymes like superoxide dismutase, catalase, and antioxidant chemicals such as ascorbic acid, glutathione, polyphenols, carotenoids, $\alpha$-tocopherol, make up the body's defence against oxidative damage. If this antioxidant system gets distorted, normal metabolic processes will be affected, giving rise to age-related pathophysiologies (Sharifi-Rad et al., 2020).

There has been a bourgeoning interest to research the use of natural antioxidants as supplements and particularly on the utilization of essential oils as key constituents in the production of confectioneries, beverages and cosmetics. These natural antioxidant sources can support the body's antioxidant system against oxidative damage (Saleh et al., 2010; Tajidin et al., 2015).

Since several synthetic drugs have resulted in deleterious side effects, researchers are beginning to seek natural and plant-based alternatives which are thought to be well-suited, acceptable, tolerable, and do not lead to any severe side effects (Balakrishnan, 2014; Oladeji et al., 2020). This research effort attempts to establishing preliminary evidence on the therapeutic potentials of EOCC in managing inflammation and oxidative stress. 


\section{MATERIALS AND METHOD}

\section{Plant material sampling and preparation}

The plant leaves from Umuariaga village in Ikwuano Local Government Area (LGA), Umuahia Abia State, Nigeria, were harvested and identified by $\mathrm{Mr}$ Ibe Kalu at the Department of Forestry, Michael Okpara University of Agriculture Umudike as Cymbopogon citratus. The leaves were washed to remove dirt and debris. This was followed by air drying under shade at room temperature $\left(25 \pm 2^{\circ} \mathrm{c}\right)$ for seven (7) days to attain a uniform weight. The dried leaves were milled using an electrical miller to powdered form. The extraction of essential oil followed immediately.

\section{Essential oil extraction}

Extraction was performed using a Soxhlet extractor and $\mathrm{n}$-hexane at a ratio of $1: 10 \mathrm{w} / \mathrm{v}$. The temperature was set at $35^{\circ} \mathrm{C}$ throughout the process. This set up was allowed to reflux continuously until all compounds in the plant material were exhaustively collected. The extract obtained was concentrated using a rotary extractor. The concentrated extract was transferred to a sterile clean container and stored in a refrigerator at $4^{\circ} \mathrm{C}$ until time for further analysis (GCMS, antioxidant and anti-inflammatory analysis).

\section{GC-MS analysis}

The essential oils composition of the extract was analyzed using a gas chromatograph (HewlettPackard Agilent 6890N, Palo Alto, CA, USA) coupled with an Agilent mass selective detector, driven by Agilent Chemstation software (Agilent Technologies, Palo Alto, CA, USA). A DB-5SIL MS capillary column was used $(30 \mathrm{~m} \times 0.25 \mathrm{~mm} \times 0.25 \mu \mathrm{m})$. The carrier gas was ultra-pure helium at a flow rate of $1.0 \mathrm{ml} / \mathrm{min}$ and a linear velocity of $37 \mathrm{~cm} / \mathrm{s}$. The injector temperature was set at $250{ }^{\circ} \mathrm{C}$, and the oven temperature programmed at $60{ }^{\circ} \mathrm{C}$ to $280{ }^{\circ} \mathrm{C}$ at a rate of $10^{\circ} \mathrm{C}$ with a hold time of $3 \mathrm{~min}$. Injections of $1 \mathrm{~mL}$ were made in the splitless mode with a manually split ratio of 1:0. The mass spectrometer operated in the electron ionization mode at $70 \mathrm{eV}$ and electron multiplier voltage at $1859 \mathrm{~V}$. Other MS operating parameters were as follows: ion source temperature $230{ }^{\circ} \mathrm{C}$, quadrupole temperature $150{ }^{\circ} \mathrm{C}$, solvent delay 4 min and scan rage 50-700 a.m.u. Total GC running time was $22 \mathrm{~min}$, and the compounds were identified by direct comparison of the retention times (RT) and mass fragmentation pattern with those from the National Institute of Standards and Technology (NIST) library.

\section{Estimation of total phenols}

Total plant phenolics was determined spectrophotometrically using $10 \mathrm{mg} / \mathrm{mL}$ extract solution in methanol. A mix of $0.5 \mathrm{~mL}$ methanolic solution of extract, $2.5 \mathrm{~mL}$ of $7.5 \% \mathrm{NaHCO}_{3}$, and $2.5 \mathrm{~mL}$ of $10 \%$ Folin-Ciocalteu's reagent dissolved in water was used as reaction mixture. In tandem, a solution of $0.5 \mathrm{~mL}$ methanol, $2.5 \mathrm{~mL}$ of $7.5 \%$ of $\mathrm{NaHCO}_{3}$ and $2.5 \mathrm{~mL} \quad 10 \%$ Folin-Ciocalteu's reagent dissolved in water was used as blank. Sample and blank were incubated at $45^{\circ} \mathrm{C}$ for 45 min using a thermostat, and absorbance was measured at $\lambda \max =765 \mathrm{~nm}$. A similar procedure was followed using graded concentrations of Gallic acid $(12.5 \mathrm{mg} / \mathrm{L}, 25 \mathrm{mg} / \mathrm{L}, 50 \mathrm{mg} / \mathrm{L}, 75 \mathrm{mg} / \mathrm{L}, 100$ $\mathrm{mg} / \mathrm{L}$ and $150 \mathrm{mg} / \mathrm{L}$ ) . Using the values obtained, a standard/reference curve was then constructed. Gallic acid standard equation obtained was $\mathrm{y}=$ $0.0359 x-0.4562\left(R^{2}=0.9904\right)$. Mean absorbance of the triplicate samples was also calculated, and extrapolations were made using the standard curve to determine the total phenolic concentration $(\mathrm{mg} / \mathrm{mL})$. Total phenolic levels in essential oils was then expressed as gallic acid equivalent ( $\mathrm{mg}$ of GAE/g of extract).

\section{Estimation of total flavonoids}

Spectrophotometric assay as portrayed by Quettier et al., (2000), was used to determine the total flavonoid content of the essential oil. $1 \mathrm{~mL}$ of 1 $\mathrm{mg} / \mathrm{mL}$ methanolic extract and $1 \mathrm{~mL}$ of $2 \%$ methanolic solution of $\mathrm{AlCl}_{3}$ was contained in the sample, which was incubated at room temperature for 30mins. The absorbance of the sample was then measured at $\lambda \max =415 \mathrm{~nm}$. With the same protocol, a standard curve was constructed using serial dilutions of quercetin $(12.5 \mathrm{mg} / \mathrm{L}, 25 \mathrm{mg} / \mathrm{L}$, $50 \mathrm{mg} / \mathrm{L}, 75 \mathrm{mg} / \mathrm{L}, 100 \mathrm{mg} / \mathrm{L}$ and $150 \mathrm{mg} / \mathrm{L}$ ), and a standard curve $(\mathrm{y}=0.024 \mathrm{x}-0.067)$ was constructed with $\mathrm{R}^{2}=0.997$. The mean absorbance of triplicate samples was extrapolated on the calibration curve to determine the total flavonoid level $(\mathrm{mg} / \mathrm{mL})$ of the essential oil, which was expressed as quercetin equivalent ( $\mathrm{mg}$ of $\mathrm{QEC} / \mathrm{g}$ of extract).

\section{DPPH radical scavenging assay}

With some modification, spectrophotometric assay of free radical DPPH (2,2- diphenyl-1-picryl hydrazyl) scavenging activity as demonstrated by Mensor et al., (2001) was used to ascertain the antioxidant potentials of EOCC. The reference standard used was vitamin $\mathrm{C}$ (at different concentrations $25,50,100,200$ and $400 \mu \mathrm{g} / \mathrm{mL}$ ). $1 \mathrm{mg} / \mathrm{mL}$ ethanolic $(98 \%)$ solution of stock EOCC was prepared and diluted to several $\mu \mathrm{g} / \mathrm{mL}$ 
concentrations $(25,50,100,200$ and $400 \mu \mathrm{g} / \mathrm{mL})$. $1.0 \mathrm{~mL}$ of $0.3 \mathrm{mM}$ DPPH was also prepared and mixed with $3.0 \mathrm{~mL}$ of the sample (serial dilutions of EOCC extract) and also $3.0 \mathrm{~mL}$ of the standard solution. The mixture was homogenized, and the reaction was allowed for 60minutes at room temperature in the dark. Absorbance was read at $520 \mathrm{~nm}$ to ascertain the ability of essential oil to reduce 2,2- diphenyl-1-picrylhydrazyl to 2,2diphenyl-1-picryl hydrazine through a colour change detectable by the spectrophotometer. Values obtained were used to compute the corresponding percentage antioxidant activity $(\% \mathrm{AA})$, and the least square regression method was applied to determine the half-maximal inhibitory concentration $\left(\mathrm{IC}_{50}\right)$ of the extract as well as the coefficient of determination $\left(\mathrm{R}^{2}\right)$. Samples were treated in triplicate, and DPPH radical scavenging activity was obtained using $\% D P P H$ radical scavenging activity $=$ $\frac{A 0-A 1}{A 0} X 100$

where: $\mathrm{A}_{0}=$ absorbance of the control, $\mathrm{A}_{1}=$ Absorbance of DPPH solution + sample extract/standard.

\section{Ferric reducing antioxidant power (FRAP) assay}

Following some modification, the FRAP assay, as demonstrated by Benzei and Strain (1996) was used to determine the antioxidant capability of the essential oil. A 1:1:10 mix of $\mathrm{FeCl}_{3} \cdot 6 \mathrm{H}_{2} \mathrm{O}$ (20 $\mathrm{mmol} / \mathrm{L}$ ) solution, 2, 4, 6-Tri (2-pyridyl)-s-triazine $(10 \mathrm{mM}$ in $40 \mathrm{mM} \mathrm{HCl})$ solution and acetate buffer (300 mM, pH 3.6) respectively was used as the working FRAP reagent. After warming the FRAP reagent at $37^{\circ} \mathrm{C}, 3 \mathrm{~mL}$ was measured and vigorously mixed with $10 \mu \mathrm{M}$ of the sample solution. The reaction mixture was then incubated for 30 minutes at room temperature. At $\lambda \max =$ $593 \mathrm{~nm}$ and, between 30 seconds intervals, the absorbance of each sample was read for 4 minutes. The standard/reference curve was constructed by making use of a standard solution of aqueous $\mathrm{Fe}^{2+}$ solution within the range of $100-1000$ $\mu \mathrm{mol} / \mathrm{L}$, and the FRAP estimates $(\mu \mathrm{mol} \mathrm{Fe}(\mathrm{II}) / \mathrm{L}$ ) of each sample was extrapolated using the least square regression technique. Vitamin C (Ascorbic Acid) was used as the reference standard.

\section{Determination of anti-inflammatory activity Blood collection}

The effects of lemongrass essential oil on the hemolysis of HRBC (human red blood cell) in hypotonic saline solution was evaluated as described by Anosike et al. (2012). Whole blood sample $(5 \mathrm{~mL})$ was collected from a healthy donor that has not received an anti-inflammatory drug (NSAIDs) in the past 10 days into heparinized tubes. $5 \mathrm{~mL}$ of heparinized blood samples were centrifuged for 10 minutes at 3000rpm. The HRBC was repeatedly washed with normal saline by centrifugation as portrayed by Anosike et al. (2012) until the supernatant was clear. Red blood pellets were then dissolved in a volume of normal saline equal to the volume of the supernatant. The volume of the dissolved HRBC pellets obtained was measured and reconstituted as a $0.4 \% \mathrm{v} / \mathrm{v}$ suspension with isotonic buffer solution $(\mathrm{pH} 7.0$, and containing $3.394 \mathrm{~g}$ of $\mathrm{NaH}_{2} \mathrm{PO}_{4}$, and 20.214 of $\mathrm{Na}_{2} \mathrm{HPO}_{4}$ in $1000 \mathrm{~mL}$ of distilled water). The reconstituted HRBC (resuspended supernatant) were utilized for the assay.

\section{Hypotonic induced haemolysis}

$0.1 \mathrm{~mL}$ of the suspension (of the HRBC) was introduced into test tubes holding distinct concentrations $(25-400 \mu \mathrm{g} / \mathrm{mL})$ of lemongrass essential oil dissolved in hypotonic saline solution in triplicate. The mixtures were incubated at $37{ }^{\circ} \mathrm{C}$ for 3 minutes and later centrifuged at $3000 \mathrm{rpm}$ for 5 minutes. The absorbance of the supernatants was read at $560 \mathrm{~nm}$. While $240 \mu \mathrm{g} / \mathrm{mL}$ diclofenac was used as reference standard, an hypotonic saline solution served as control. The percentage inhibition was computed using the formula

$H(\%)=\frac{A A-B B}{A A} \times 100$

where: $\mathrm{AA}=$ absorbance of control, $\mathrm{BB}=$ absorbance of test substance

\section{Heat-induced hemolysis assay}

First, isotonic phosphate buffer solution was used to dissolve the extract samples. Secondly, $3 \mathrm{~mL}$ of graded extract doses $(25,50,100,200$ and $400 \mu \mathrm{g} / \mathrm{mL}$ ) were assembled in quadruplicate sets per dose. Also, $3 \mathrm{~mL}$ of $200 \mu \mathrm{g} / \mathrm{mL}$ diclofenac and $3 \mathrm{~mL}$ of the vehicle were prepared in control centrifuge tubes. $0.1 \mathrm{~mL}$ HRBC suspension was introduced to all sample tubes and then gradually mixed together. A pair of tubes were maintained at $-10^{\circ} \mathrm{C}$ in a freezer for 20 minutes. At the same time, the other pair of the centrifuge tubes were incubated at $54^{\circ} \mathrm{C}$ for 20 minutes in a regulated water bath. Thereafter, the tubes were spined for 3 min at $1300 \mathrm{~g}$, and the haemoglobin concentration of the supernatant was measured at an absorbance of $540 \mathrm{~nm}$ with the aid of Spectronic 21D (Milton Roy) Spectrophotometer. The percentage inhibition of hemolysis by the essential oils was computed using the formula: 
$\%$ Inhibition of Hemolysis $=1-\frac{O D 2-O D 1}{O D 3-O D 1} \times 100$

where:

$\mathrm{OD}_{1}=$ absorbance of test sample unheated

$\mathrm{OD}_{2}=$ absorbance of test sample heated

$\mathrm{OD}_{3}=$ absorbance of control sample heated

\section{Statistical analysis}

Results obtained in this study were analyzed with the aid of SPSS version 22.0. Values were compared using analysis of variance (ANOVA) and Tukey's multiple comparison test to verify if they were significantly different. Statistical significance was set at $\mathrm{p}<0.05$.

\section{GC-MS screening of the EOCC (lemongrass)}

Following comparison with the NIST electronic Library, 25 bioactive compounds were identified as constituents of the essential oil from C. citratus as presented in Table 2 below. Mass spectra used for this comparison is also shown in Figure 1. triplicate determinations. The total flavonoid was $352.82 \pm 3.45 \mathrm{mg} \mathrm{QEC} / \mathrm{g}$ of extract, while; the total phenol content was $49.83 \pm 0.39 \mathrm{mg} \mathrm{GAE} / \mathrm{g}$ of extract.

Table 1. Total flavonoid and phenol and contents of EOCC (Lemon Grass) leaves

\begin{tabular}{lll}
\hline Sample & Total flavonoid* & Total phenol** \\
& & \\
\hline Lemongrass & $352.82 \pm 3.45$ & $49.83 \pm 0.39$ \\
\hline
\end{tabular}

EOCC = Essential oil of Cymbopogon citratus leaves;

* = mg QEC/g of extract (Quercetin equivalent);

$* *=\mathrm{mg}$ GAE /g of extract (gallic acid equivalent)

Table 2: GC-MS screening of the essential oil of Cymbopogon citratus

\begin{tabular}{|c|c|c|c|c|}
\hline Peak & Name of compound & $\begin{array}{l}\text { Retention } \\
\text { (minutes) }\end{array}$ & $\begin{array}{l}\text { Percentage } \\
\text { concentration }(\%)\end{array}$ & Formula \\
\hline 1 & $\alpha$-citral & 4.560 & 3.720 & $\mathrm{C}_{10} \mathrm{H}_{16} \mathrm{O}$ \\
\hline 2 & $\beta$-citral & 4.922 & 2.522 & $\mathrm{C}_{10} \mathrm{H}_{6} \mathrm{O}$ \\
\hline 3 & Geraniol & 5.550 & 1.127 & $\mathrm{C}_{10} \mathrm{H}_{18} \mathrm{O}$ \\
\hline 4 & Geranyl oleate & 5.612 & 0.845 & $\mathrm{C}_{28} \mathrm{H}_{50} \mathrm{O}_{2}$ \\
\hline 5 & Citronella & 6.120 & 6.383 & $\mathrm{C}_{10} \mathrm{H}_{18} \mathrm{O}$ \\
\hline 6 & Terpinollene & 6.710 & 2.577 & $\mathrm{C}_{10} \mathrm{H}_{16}$ \\
\hline 7 & Geranyl acetate & 6.804 & 4.943 & $\mathrm{C}_{12} \mathrm{H}_{20} \mathrm{O}_{2}$ \\
\hline 8 & Myrcenyl acetate & 7.079 & 9.703 & $\mathrm{C}_{12} \mathrm{H}_{20} \mathrm{O}_{2}$ \\
\hline 9 & Terpinenyl acetate & 7.308 & 7.579 & $\mathrm{C}_{12} \mathrm{H}_{20} \mathrm{O}_{2}$ \\
\hline 10 & 2-Nonanone & 7.914 & 1.652 & $\mathrm{C}_{9} \mathrm{H}_{18} \mathrm{O}$ \\
\hline 11 & Endo-borneol & 8.080 & 3.662 & $\mathrm{C}_{10} \mathrm{H}_{18} \mathrm{O}$ \\
\hline 12 & Linalyl acetate & 8.257 & 2.468 & $\mathrm{C}_{12} \mathrm{H}_{20} \mathrm{O}_{2}$ \\
\hline 13 & $\alpha$-pinene & 8.395 & 0.514 & $\mathrm{C}_{10} \mathrm{H}_{16}$ \\
\hline 14 & $\beta$-pinene & 11.445 & 1.142 & $\mathrm{C}_{10} \mathrm{H}_{16}$ \\
\hline 15 & Limonene & 11.891 & 0.504 & $\mathrm{C}_{10} \mathrm{H}_{16}$ \\
\hline 16 & Linalool & 12.154 & 0.548 & $\mathrm{C}_{10} \mathrm{H}_{18} \mathrm{O}$ \\
\hline 17 & Caryophyllene & 15.364 & 8.997 & $\mathrm{C}_{15} \mathrm{H}_{24}$ \\
\hline 18 & Isocaryophyllene & 16.056 & 0.584 & $\mathrm{C}_{15} \mathrm{H}_{24}$ \\
\hline 19 & Fenitrothion & 17.475 & 1.004 & $\mathrm{C}_{9} \mathrm{H}_{12} \mathrm{NO}_{5} \mathrm{PS}$ \\
\hline 20 & Methyl parathion & 17.790 & 0.625 & $\mathrm{C}_{8} \mathrm{H}_{10} \mathrm{NO}_{5} \mathrm{PS}$ \\
\hline 21 & Retinol & 17.830 & 1.194 & $\mathrm{C}_{20} \mathrm{H}_{30} \mathrm{O}$ \\
\hline 22 & 4-androsten-3 $\beta, 6 \beta$-diol-17-one & 17.962 & 0.659 & $\mathrm{C}_{19} \mathrm{H}_{28} \mathrm{O}_{3}$ \\
\hline 23 & $3-\beta-5 \alpha-6 \beta$-trihydroxy androstan-17-one & 18.042 & 5.829 & $\mathrm{C}_{19} \mathrm{H}_{30} \mathrm{O}_{4}$ \\
\hline 24 & 4 -androsten-3 $\beta$-6 $\beta$-diol-17-one & 19.821 & 1.260 & $\mathrm{C}_{19} \mathrm{H}_{28} \mathrm{O}_{3}$ \\
\hline 25 & Androst-5-ene-3,17-dione & 20.331 & 0.659 & $\mathrm{C}_{19} \mathrm{H}_{26} \mathrm{O}_{2}$ \\
\hline
\end{tabular}




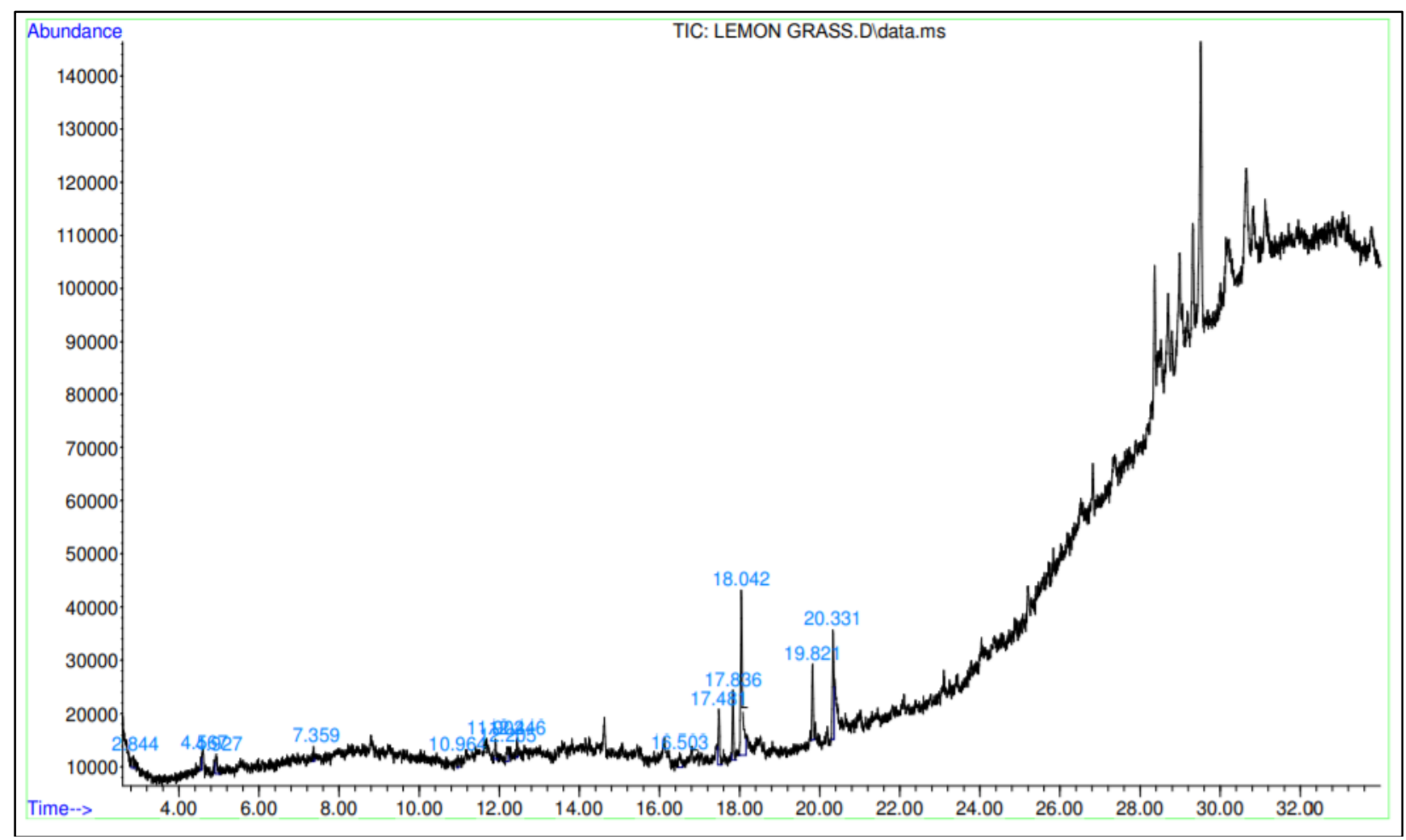

Figure 1. GC-MS chromatogram of Cymbopogon citratus methanol leaves extract

\section{In vitro anti-inflammatory activities of EOCC Hypotonic induced haemolysis assay}

The result of the HRBC membrane stabilization activity in hypotonic solution (Figure 2) indicates that there was a concentration-dependent rise in activity from 50 to $400 \mu \mathrm{g} / \mathrm{mL}$. The lowest antiinflammatory activity was detected at $50 \mu \mathrm{g} / \mathrm{mL}$ with $34.40 \%$ inhibition, while highest antiinflammatory activity was detected at concentration of $400 \mu \mathrm{g} / \mathrm{mL}$ with $54.40 \%$ inhibition and was significantly higher compared to that of the standard $(13.09 \%$ at $200 \mu \mathrm{g} / \mathrm{mL})$. Since HRBC membrane lysis act in similar fashion as the lysosomal membrane rupture, its stabilization using the extract may follow a similar mechanism as NSAID suppression of inflammatory pathways. Thus, \% inhibition of hypotonic-induced haemolysis is a measure of the anti-inflammatory activity of EOCC. The halfmaximal inhibitory concentration $\left(\mathrm{IC}_{50}\right)$ for EOCC was $345.3504 \pm 10.97 \mu \mathrm{g} / \mathrm{mL}$.

\section{Heat-induced hemolysis assay}

The result of heat-induced hemolysis assay (Figure 3), shows a dose-dependent rise in antiinflammatory response by EOCC. The lowest antiinflammatory response was detected at $25 \mu \mathrm{g} / \mathrm{mL}$ with $0.55 \%$ inhibition, while the highest antiinflammatory activity was detected at a concentration of $400 \mu \mathrm{g} / \mathrm{mL}$ with $92.27 \%$ inhibition. At an equivalent concentration of 200 $\mu \mathrm{g} / \mathrm{mL}$ EOCC showed a significantly higher percentage inhibition $(42.43 \pm 4.27 \%)$ compared to the standard $(25.49 \pm 0.70 \%)$. Half maximal inhibitory concentration $\left(\mathrm{IC}_{50}\right)$ for EOCC was $238.39 \pm 17.68 \mu \mathrm{g} / \mathrm{mL}$.

\section{In vitro antioxidant activities of $\mathrm{EOCC}$}

DPPH scavenging response of the EOCC was concentration-dependent, and ascorbic acid has been used as a reference standard. The maximum concentration of EOCC used in this study $(400 \mu \mathrm{g} / \mathrm{mL})$ gave the highest DPPH scavenging activity compared to the other concentrations of EOCC. Figure 4 shows the linear trend, the least square regression equation and the coefficient of determination.

Also, Figure 5 shows the ferric reducing antioxidant power (FRAP) of EOCC using ascorbic acid as the reference standard. There was a dose-dependent increase in FRAP of EOCC from 25 to $400 \mu \mathrm{g} / \mathrm{mL}$ in relation to the standard.

$50 \%$ inhibitory concentrations $\left(\mathrm{IC}_{50}\right)$ for EOCC and ascorbic acid are presented in Table 3 . Antioxidant capacity was inversely proportional to the half-maximal inhibitory concentration $\left(\mathrm{IC}_{50}\right)$, and values obtained for EOCC were comparable with that of Ascorbic acid. 


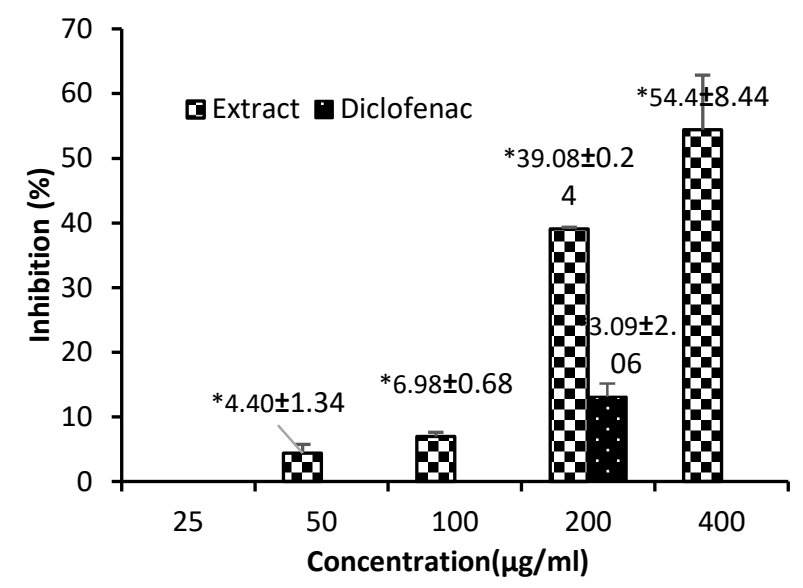

Figure 2. Percentage inhibition of hypotonic-induced haemolysis with EOCC. *Values are means \pm standard deviations of triplicate determination

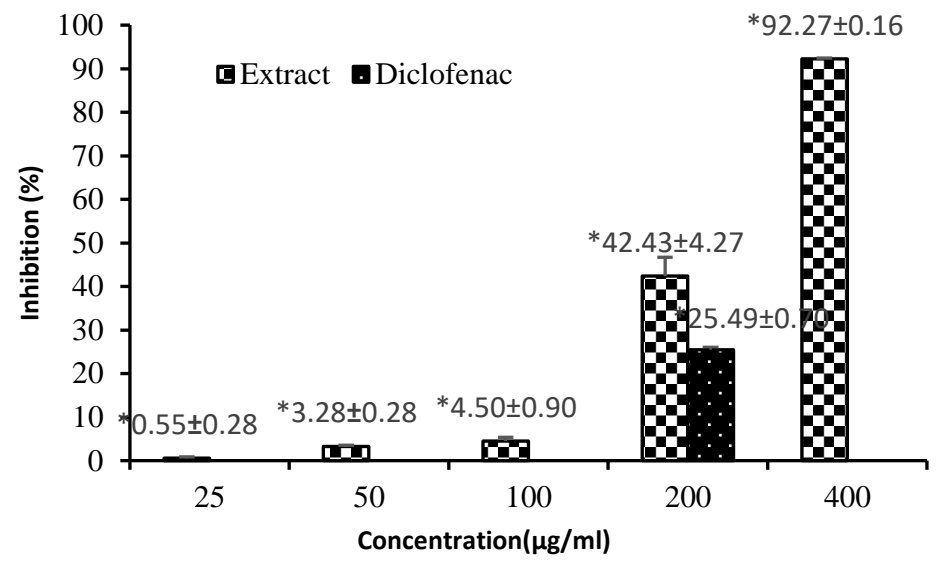

Figure 3. Percentage inhibition of heat-induced haemolysis with EOCC. $*$ Values are means \pm standard deviations of triplicate determinations

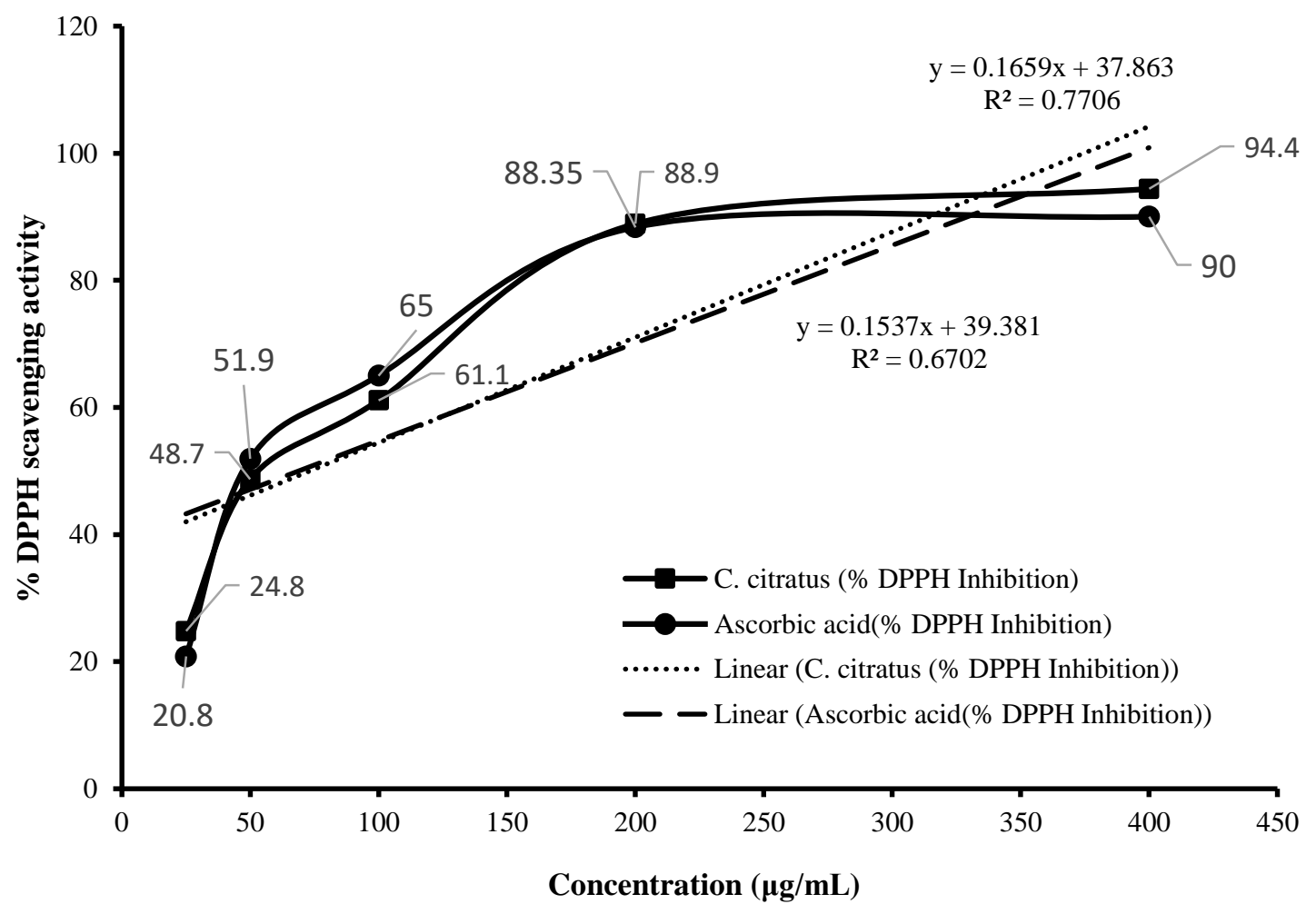

Figure 4. DPPH scavenging effect of EOCC, with Ascorbic acid as standard.

Table 3: Half maximal inhibitory concentrations $\left(\mathrm{IC}_{50}\right)$ for EOCC and ascorbic acid.

\begin{tabular}{lll}
\hline Antioxidant assays & \multicolumn{2}{c}{$\mathrm{IC}_{50}$ value } \\
\cline { 2 - 3 } & EOCC & Ascorbic acid \\
DPPH $(\mu \mathrm{g} / \mathrm{mL})$ & $73.16 \pm 12.89$ & $69.09 \pm 4.52$ \\
FRAP $(\mu \mathrm{mol} \mathrm{Fe}(\mathrm{II}) / \mathrm{L})$ & $656.01 \pm 0.01$ & $246.79 \pm 0.01$ \\
\hline
\end{tabular}




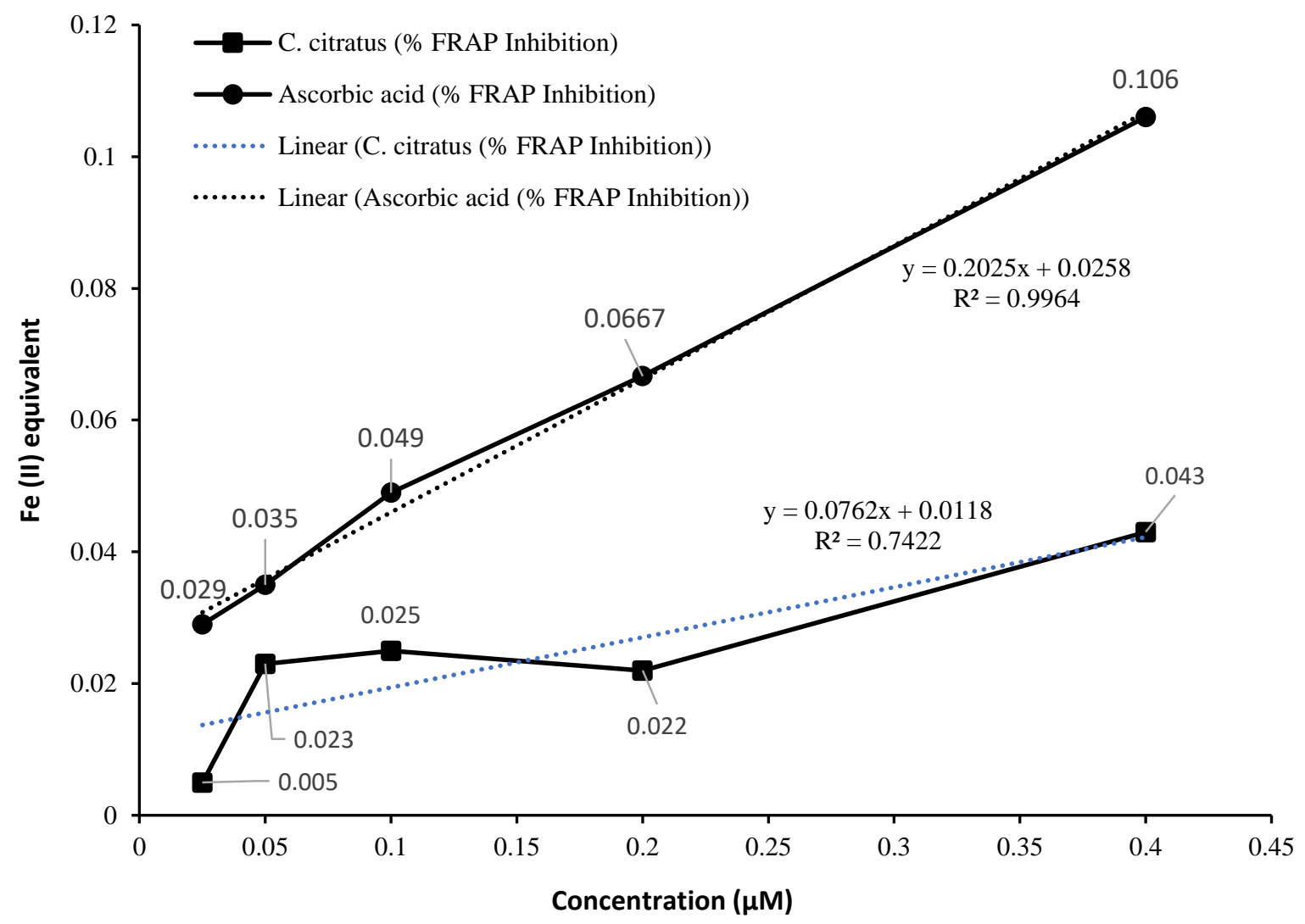

Figure 5. Ferric reducing antioxidant power (FRAP) of EOCC.

\section{DISCUSSION}

Cymbopogon citratus has been reported to contain several beneficial phytochemicals and compounds which have made its essential oil, a vital starting material in the production of many pharmaceuticals and cosmetics (Acimovic et al., 2019; Boukhatem et al., 2014; Tayupanta, 2016). Phytochemicals such as flavonoids and phenolics have been reported by many scholars to abate oxidative stress, and exhibit a broad spectrum of therapeutic potentials including anti-diabetes, antinflammatory and anti-cancer (e.g. Al-Snafi et al., 2020; Hamzah et al., 2013; Karak, 2019; Mirghani et al., 2012; Tungmunnithum et al., 2018; Unuigbe et al., 2019). This necessitated the research on the anti-inflammatory and antioxidant properties of EOCC, including the total flavonoid and phenol levels.

Medicinal and aromatic plants are well known to contain phenols and flavonoids; these compounds have drawn considerable attention because of their potential antioxidant activities, demonstrating their beneficial implications for human health (Maizura et al., 2011; Unuigbe et al., 2019). Total phenol $(49.83 \pm 0.39 \mathrm{mg} \mathrm{GAE} / \mathrm{g}$ of extract) and total flavonoid $\quad(352.82 \pm 3.45 \mu \mathrm{g}$ QEC/g of extract) reported in this study for $\mathrm{C}$. citratus grown in
Umuahia is remarkably higher than those reported by Godwin et al., (2014) for C. citratus harvested at different locations in Southern Ghana; also, total phenol was notably higher when compared with values reported by Olaiya et al., (2016) and Sete da Cruz (2020) however, total flavonoid was comparable to those reported by Olaiya et al., (2016) for C. citratus grown in Western Nigeria. However, alongside the choice of solvent used for extraction, the absence or presence of non-phenolic antioxidant metabolites that can reduce FolinCiocalteu may influence the total phenol concentration of plant extracts (Jolayemi et al., 2020). The high amounts of total phenol and total flavonoids of EOCC, as shown in Table 1, has strong implications for the (highly significantly) antioxidant and anti-inflammatory potential of EOCC, and this is in line with previous studies by Gebashe et al., (2020), Olaiya et al., (2016) and Godwin et al., (2014), on the phytochemical profile and therapeutic potentials of Cymbopogon citratus. Particularly, polyphenolic compounds scavenge free radicals by donating protons from their hydroxyl group, which stabilizes these radicals (Goupy et al., 2003). Also, flavonoids can decrease the pro-oxidant action of metal ions by chelating them, thus inhibiting the production of reactive oxygen species. Their role as antioxidants 
primarily explains several other pharmacological characteristics, including neuroprotection and antiinflammation (Misiak, \& Lodyga-Chruscinska, 2010).

In respect to this study, a GC-MS assay was done on the essential oil of Cymbopogon citratus (EOCC). Results obtained show that the plant contained a wide range of phyto-compounds which may be responsible for its therapeutic potentials. The total peak area $(\%)$ and retention times (RT) depicted twenty-five absorption peaks indicating the presence of twenty-five (25) phyto-compounds in the extract. The identified phyto-compounds comprise mainly hydrocarbons, terpenes, ketones, aldehydes, alcohols, esters, phenols, flavonoids, fatty acids and some other compounds (Shruti, 2015).

The GC-MS chromatogram of EOCC is presented in figure 1 above. The most significant compounds identified include myrcenyl acetate $(9.703 \%)$, caryophyllene $(8.997 \%)$, citronella $(6.383 \%), 3-\beta-$ $5 \alpha-6 \beta$-trihydroxy androstan-17-one (5.829\%), geranyl acetate $(4.943 \%)$, and $\alpha$-citral $(3.720 \%)$. However, other parallel studies identified geranial, neral and myrcene as three relatively high components of Cymbopogon citratus (Bassolé et al., 2011; Boukhatem et al., 2014, Olivero-Verbel et al., 2010; Zaki et al., 2018). Also, Hanaa et al., (2012) reported a discrepancy in the proportion but consistent makeup of phytochemical component for C. citratus obtained within the same locality but dried using different methods. This implies that variation in the phytochemical composition of C. citratus is mainly due to geographical origin, plant species (Oladeji et al., 2019), climatic factors, age of the plant (Lawal et al., 2017), harvesting factors (Coelho et al., 2016) method employed during distillation (Ganjewala, 2009) and storage time of the sample plant (Akinkunmi et al., 2016).

The presence of these therapeutically active compounds lays credence to the use of Cymbopogon citratus essential oil in ethnopharmacology (Avoseh et al., 2015; Mirghani et al., 2012). For example, results from a recent study by Salaria et al. (2020) has shown that caryophyllene has higher binding energy when matched with diclofenac and not only binds better to the Human peroxiredoxin-5 compared to ascorbic acid and $\alpha$-Tocopherol but also showed greater safety thus, providing a better alternative for antioxidant and anti-inflammatory therapy.

Anti-inflammatory agents act to maintain the integrity of the lysosomal and erythrocyte membranes by stabilizing membrane proteins (Anosike et al., 2012; Mahendra et al., 2016).
However, during inflammation, lysosomal enzymes get released into the cytosol, where they trigger metabolic processes that result in damage of surrounding tissues. Thus, anti-inflammatory therapy acts by inhibiting the release of lysosomal enzymes through the stabilization of lysosomal membrane proteins (Mahendra et al., 2016).

During this research, membrane stabilization techniques were used to assess the antiinflammatory capability of $C$. citratus essential oil (EOCC). The results revealed that Cymbopogon citratus essential oil significantly impeded the erythrocyte hemolysis under heat stress $\left(\mathrm{IC}_{50}=\right.$ $238.39 \pm 17.68 \mu \mathrm{g} / \mathrm{mL}$ ) and in hypotonic saline solution $\left(\mathrm{IC}_{50}=345.3504 \pm 10.97 \mu \mathrm{g} / \mathrm{mL}\right)$ following a concentration-dependent fashion. Also, the percentage inhibition was significantly higher compared to the standard drug diclofenac. This suggests that Cymbopogon citratus essential oil contains bioactive molecules which can be isolated and concentrated for anti-inflammatory drugs. Cymbopogon citratus essential oil may have stabilized the HRBC membrane proteins, thereby preventing its rupture as reported by Mahendra et al. (2016). Also, it is possible that the antiinflammatory activity exhibited by EOCC is as a result of the ability of some of its constituent compounds to impede the synthesis of proinflammatory cytokines (Sforcin et al., 2009); a good example is citral which is mainly a blend of neral ( $\beta$-citral) and geranial ( $\alpha$-citral) (Zaki, 2018). This is buttressed by the findings of a previous study by Bachiega and Sforcin (2011). According to them, citral exerts immunomodulatory action through the inhibition of interleukin (IL) $-1 \beta$ and interleukin-6 (IL-6) synthesized by macrophages both before and after a lipopolysaccharide challenge (Bachiega \& Sforcin, 2011). Citral blocks lipopolysaccharide-induced stimulation of nuclear factor kappa-B (NF-kB) by suppressing the phosphorylation of I-kappa-B (I-kB), which further inhibits, p50 and p65 translocation to the nucleus; overall, preventing gene expression of various cytokines (Lee et al., 2007). Our study shows significant levels of citral in EOCC, suggesting the suitability of EOCC as a preventive and therapeutic anti-inflammatory agent.

Antioxidant phytochemicals perform vital functions against age-related ailments, including cancer, high blood pressure and cardiovascular disease, either by stimulating the release of endogenous antioxidants or acting directly to scavenge reactive oxygen species and free radicals (Jamuna et al., 2017). The results of this study show that the reducing power and antioxidant potential of EOCC $\left(\mathrm{IC}_{50}=73.16 \pm 12.89 \mu \mathrm{g} / \mathrm{mL}\right)$ is 
comparable to that of standard vitamin $\mathrm{C}$ ( $L$ ascorbic acid), suggesting its role in free radical inhibition as a proton donator. These findings are in consonance with previous studies (Hasim et al., 2015; Jamuna et al., 2017; Salaria et al., 2020). The antioxidant properties of EOCC are ascribable to phytochemicals with redox potential such as phenolic compounds (Unuigbe et al., 2019), flavonoids, alkaloids and sulphides (Hasim et al.,

\section{CONCLUSION}

Our study reveals that the essential oil from Cymbopogon citratus (EOCC) possess antiinflammatory and antioxidant properties in vitro as shown by the highly significant percentage inhibition of human red blood cell membrane hemolysis, DPPH and FRAP oxidation which were possibly enhanced by the total flavonoid and phenol contents. The results show that the
2015). In our study, $400 \mu \mathrm{g} / \mathrm{mL}$ concentration showed the highest antioxidant activity.

Also, concentration-dependent scavenging activity of EOCC against FRAP radicals was observed. In line with findings by Unuigbe et al. (2019), our results suggest that EOCC is an excellent antioxidant agent and may guard against oxidative stress by sequestering Iron II ions.

percentage inhibitory activity is dose-dependent and half-maximal inhibitory concentration $\left(\mathrm{IC}_{50}\right)$ were comparable to those of standard drugsdiclofenac and ascorbic acid. However, it is suggested that further studies be carried out to rule out any possibility of toxicity and to purify and concentrate the active components in order for the oil to be used as an antioxidant and therapy for inflammation.

Conflict of interest: The Authors declare that they have no conflict of interest

\section{REFERENCES}

1. Acimovic, M., Cabarkapa, I., Cvetkovic, M., Stankovic, J., Kiprovski, B., Gvozdenac, S., \& Puvača, N. (2019). Cymbopogon citratus (DC.) Staph: chemical composition, antimicrobial and antioxidant activities, use in medicinal and cosmetic purpose. Journal of Agronomy, Technology and Engineering Management, 2, 344-360. ISSN: 2620-1755.

2. Ademuyiwa, A., \& Grace, K. (2015). The effects of Cymbopogon citratus (Lemongrass) on the antioxidant profiles Wistar albino rats. Merit Research Journal, 3, 51-58. https://meritresearchjournals.org/mms/content/2015/June/Ademuyiwa\%20et\%20al.pdf. ISSN: 2350 2266

3. Aiyeloja \& Bello (2006). Ethnobotanical potentials of common herbs in Nigeria: A case study of Enugu state. Educational Research and Review, 1 (1), 16-22. https://eric.ed.gov/?id=EJ903173. ISSN: ISSN1990-3839

4. Akinkunmi, E.O., Oladele, A., Esho, O. \& Odusegun, I. (2016). Effects of storage time on the antimicrobial activities \& composition of lemongrass oil. Journal of Applied Research on Medicinal and Aromatic Plants, 3(3) (2016) 105-111. https://doi.org/10.1016/j.jarmap.2016.02.005

5. Al-Snafi, A. (2020). Phenolics and flavonoids contents of medicinal plants, as natural ingredients for many therapeutic purposes- A review. IOSR Journal of Pharmacy (IOSRPHR), 10(7):42-81. ISSN: 2250-3013

6. Anosike, C. A., Obidoa, O. \& Ezeanyika, L. U. (2012). Membrane stabilization as a mechanism of the anti-inflammatory activity of methanol extract of garden egg (Solanum aethiopicum). DARU Journal of Pharmaceutical Sciences, 20(1):76, 22-31. DOI: 10.1186/2008-2231-20-76

7. Avoseh, O., Oyedeji, O., Rungqu, P., Nkeh-Chungag, B. \& Oyedeji, A. (2015). Cymbopogon species; ethnopharmacology, phytochemistry and the pharmacological importance. Molecules, 20(5), 7438-7453. DOI: $10.3390 /$ molecules 20057438

8. Bachiega, T.F. \& Sforcin, J.M. (2011). Lemongrass and Citral effect on cytokines production by murine macrophages. Journal of Ethnopharmacology, 137(1), 909-913. DOI: 10.1016/j.jep.2011.07.021

9. Bakkali, F., Averbeck, S., Averbeck, D. \& Idaomar, M. (2008). Biological effects of essential oils, a review. Food and Chemical Toxicology, 46(2), 446-475. https://doi.org/10.1016/j.fct.2007.09.106. 
10. Balakrishnan, B., Paramasivam, S. \& Arulkumar, A. (2014). Evaluation of the lemongrass plant (Cymbopogon citratus) extracted in different solvents for antioxidant and antibacterial activity against human pathogens. Asian Pacific Journal of Tropical Disease, 4(1), S134-S139. https://doi.org/10.1016/S2222-1808(14)60428-X

11. Bassolé, I.H., Lamien-Meda, A., Bayala, B.O., Obame, L.C., Ilboudo, A.J., Franz, C., Novak, J. Nebié, R.C. \& Dicko, M.H. (2011). Chemical composition \& antimicrobial activity of Cymbopogon citratus and Cymbopogon giganteus essential oils alone \& in combination. Phytomedicine, 18(12), 1070-4. DOI: $10.1016 / j . p h y m e d .2011 .05 .009$

12. Batubara, I., Suparto, I. H., Sadiah, S., Matsuoka, R. \& Mitsunaga, T. (2015). Effects of inhaled citronella oil \& related compounds on rat body weight \& brown adipose tissue sympathetic nerve. Nutrients, 7, 1859-1870. https://doi.org/10.3390/nu7031859

13. Benzie, I., \& Strain, J. (1996). The ferric reducing ability of plasma (FRAP) as a measure of "antioxidant power": the FRAP assay. Analytical Biochemistry, 239 1, 70-6. DOI:10.1006/ABIO.1996.0292

14. Boukhatem, M.N., Ferhat, A., Kameli, A., Saidi, F. \& Kebir, H.T. (2014). Lemongrass (Cymbopogon citratus) essential oil as a potent anti-inflammatory \& antifungal drugs. Libyan Journal of Medicine, 9(1), 25431. DOI: $10.3402 /$ ljm.v9.25431

15. Carson, C. F. \& Hammer, K. A. (2015). Chemistry \& bioactivity of essential oils. In, Thormar, H. (Ed.), Lipids \& Essential Oils as Antimicrobial Agents (pp. 203-238). John Wiley \& Sons. https://doi.org/10.1002/9780470976623.ch9

16. Costa, C.A., Kohn, D.O., de Lima, V.M., Gargano, A.C., Flório, J.C., Costa, M. (2011). The GABAergic system contributes to the anxiolytic-like effect of essential oil from Cymbopogon citratus (lemongrass), Journal of Ethnopharmacology, 137, (1), 828-836. DOI: 10.1016/j.jep.2011.07.003

17. Chukwuocha, U.M., Fernández-Rivera, O. \& Legorreta-Herrera, M. (2016). Exploring the antimalarial potential of whole Cymbopogon citratus plant therapy, Journal of Ethnopharmacology, 193, 517-523, DOI: $10.1016 /$ j.jep.2016.09.056

18. Chukwuma, E. C., Soladoye, M.O. \& Feyisola, R.T. (2015). Traditional medicine and the future of medicinal plants in Nigeria. Journal of Medicinal Plants Studies, 3(4), 23-29. https://www.plantsjournal.com/vol3Issue4/Issue_july_2015/3-2-49.1.pdf

19. Coelho, M., Rocha, C., Cunha, L.M., Cardoso, L., Alves, L., Lima, R.C. \& Pintado M. (2016). Influence of harvesting factors on sensory attributes and phenolic and aroma compounds composition of Cymbopogon citratus leaves infusions. Food Research International.89(2), 1029-1037. https://doi.org/10.1016/j.foodres.2016.07.008

20. Dai, J. \& Mumper, R. (2010). Plant phenolics, extraction, analysis and their antioxidant and anti-cancer properties. Molecules, 15(10), 7313-7352. DOI: $10.3390 /$ molecules 15107313

21. Fierascu, R.C., Fierascu, I., Ortan, A., Georgiev, M.I., Sieniawska, E. (2020). Innovative approaches for recovery of phytoconstituents from medicinal/aromatic plants and biotechnological production. Molecules, 25(2), 309. https://doi.org/10.3390/molecules25020309

22. Gebashe, F., Aremu, A.O., Gruz, J., Finnie, J.F., Van Staden, J. (2020). Phytochemical profiles and antioxidant activity of grasses used in South African traditional medicine. Plants, 9(3), 371. https://doi.org/10.3390/plants9030371

23. Ganjewala, D. (2009). Cymbopogon essential oils, Chemical compositions \& bioactivities. International Journal of Essential Oil Therapeutics, 3(2-3), 56-65. http,//www.theoildropper.com/wpcontent/uploads/2014/07/lemongrass-study.pdf

24. Garcia, R., Ferreira, J., Costa, G., Santos, T., Branco, F., Caramona, M. Carvalho, R., Dinis, A., Batista, M., Castel-Branco, M. \& Figueiredo, I. (2015). Evaluation of anti-inflammatory and analgesic activities of Cymbopogon citratus in vivo-polyphenols contribution. Research Journal of Medicinal Plant. 9(1). DOI: $10.3923 /$ rjmp.2015.1.13.

25. Garg, D., Muley, A., Khare, N. \& Marar, T. (2012). Comparative analysis of phytochemical profile \& antioxidant activity of some Indian culinary herbs. Research Journal of Pharmaceutical, Biological \& Chemical Sciences, 3(3), 845-854. http://rjpbcs.com/pdf/2012_3(3)/[88].pdf

26. Gilling, D. H., Kitajima, M., Torrey, J. R. \& Bright, K. R. (2014). Mechanisms of antiviral action of plant antimicrobials against murine norovirus. Applied \& Environmental Microbiology, 80(16), 48984910. DOI: $10.1128 /$ AEM.00402-14 
27. Godwin, A., Daniel, G.A., Shadrach, D., Elom, S.A., Nana Afua, K.A.-B Godsway, B., Joseph, K.G., Sackitey, N.O., Isaak, K.B. \& Wisdom, A. (2014). Determination of elemental, phenolic, antioxidant and flavonoid properties of Lemongrass (Cymbopogon citratus Stapf). International Food Research Journal. 21 ,

1971-1979. http://www.ifrj.upm.edu.my/21\%20(05)\%202014/36\%20IFRJ\%2021\%20(05)\%202014\%20Godwin\%2 0253.pdf

28. González-Rodríguez, I. I., Francisco, A. F., Moreira-Dill, L.S., Quintero, A. Guimarães, C.L.S., Fernandes, C.A.H., Takeda, A.A.S., Zanchi, F. B., Caldeira, C.A.S., Pereira, P.S., Fontes, M.R.M., Zuliani, J.P., Soares. A.M. (2020). Isolation and structural characterization of bioactive compound from Aristolochia sprucei aqueous extract with anti-myotoxic activity, Toxicon: $X, 7$. https://doi.org/10.1016/j.toxcx.2020.100049.

29. Goupy, P., Dufour, C., Loonis, M. \& Dangles, O. (2003). Quantitative Kinetic analysis of hydrogen transfer reactions from dietary polyphenols to the DPPH radical. Journal of Agricultural and Food Chemistry, 51(3),615-22. DOI: 10.1021/jf0259381

30. Gulcin, I., Buyukokuroglu, M.E., Oktay, M. \& Kufrevioglu, O.I. (2016). On the in vitro antioxidative properties of melatonin. Journal of Pineal Research, 33(3), 167-71. https://doi.org/10.1034/j.1600079X.2002.20920.x

31. Hamzah, R. U., Egwim, E.C., Kabiru, A.Y. \& Muazu, M. B. (2013) Phytochemical \& in vitro antioxidant properties of the methanolic extract of fruits of Blighia sapida, Vitellaria paradoxa and Vitex doniana. Oxidation \& Antioxidant Medical Science, 2(3), 217-223. DOI: $10.5455 /$ oams.090513.or.043

32. Hanaa, A.M., Sallam, Y.I., El-Leithy, A.S. \& Aly, S.E. (2012). Lemongrass (Cymbopogon citratus) essential oil as affected by drying methods. Annals of Agricultural Sciences, 57(2), 113-116. DOI: 10.1016/j.aoas.2012.08.004

33. Hasim, S., Falah R.D. Ayunda \& Faridah, D.N. (2015). Potential of lemongrass leaves extract (Cymbopogon citratus) as prevention for oil oxidation. Journal of Chemical and Pharmacological Research, 7 (10), 55-60. https,//www.jocpr.com/articles/potential-of-lemongrass-leaves-extractcymbopogon-citratus-as-prevention-for-oil-oxidation.pdf

34. Idm'hand, E., Msanda, F. \& Cherifi, K. (2019). Ethnopharmacological documentation of medicinal plants used in the traditional treatment of hypertension in Tarfaya province, Morocco. International Journal of Pharmacology, Phytochemistry and Ethnomedicine, 14, 16-39. DOI: $10.18052 /$ www.scipress.com/IJPPE.14.16

35. Jamuna S., Sakeena Sadullah M.S., Ashokkumar R., Gokul, S., Senguttuvan S. M., Niranjali D. S. (2017). Potential antioxidant \& cytoprotective effects of essential oil extracted from Cymbopogon citratus on OxLDL \& H2O2 LDL induced Human Peripheral Blood Mononuclear Cells (PBMC), Food Science \& Human Wellness, 6(2), 60-69. https,//doi.org/10.1016/j.fshw.2017.02.001

36. Jolayemi, O., Olanrewaju, O. \& Ogunwale, O.(2020). Exploring in Vitro Antioxidant Activity and Physicochemical Properties of Selected Under-Exploited Tropical Fruits. Acta Universitatis Cibiniensis. Series E: Food Technology, 24(2) 165-174. https://doi.org/10.2478/aucft-2020-0015

37. Karak, P. (2019). Biological activities of flavonoids: An overview. International Journal of Pharmaceutical Sciences and Research, 10, 1567-1574. DOI: 10.13040/IJPSR.0975-8232.10(4).1567$\underline{74}$

38. Lawal, O.A. Ogundajo, A.L. Avoseh, N.O. \& Ogunwe, I.A. (2017). Cymbopogon citratus. In V. Kuete (Eds.), Medicinal Spices \& Vegetables from Africa, (pp 397-423), Academic Press, DOI: 10.1016/B9780-12-809286-6.00018-2

39. Lee, H.J., Jeong, H.S., Kim, D.J., Noh, Y.H., Yuk, D.Y. \& Hong, J.T. (2007). Inhibitory effect of citral on NO production by suppression of iNOS expression \& NF-kB activation in RAW 264.7 cells. Archives for Pharmacological Research, 31(3), 342-349. DOI: 10.1007/s12272-001-1162-0.

40. Mahendra, V., Kardile, N., Umesh, B., Mahajan, N., Haidarali, M. \& Shaikh, S. (2016). Membrane stabilization assay for anti-inflammatory activity yields false-positive results for samples containing traces of ethanol \& methanol. World journal of pharmacy \& pharmaceutical sciences 5(3), 493-497. https://wjpr.net/download/article/1513745964.pdf

41. Maizura, M., Aminah, A. \& Wan Aida, W.M. (2011). Total phenolic content \& antioxidant activity of kesum (Polygonum minus), ginger (Zingiber officinale) \& turmeric (Curcuma longa) extract. International Food Research Journal, 18, 529-534. 
42. Mensor, L.L., Menezes, F.S., Leitão, G.G., Reis, A.S., Santos, T.C., Coube, C.S., \& Leitão, S.G. (2001). Screening of Brazilian plant extracts for antioxidant activity by the use of DPPH free radical method. Phyto-theoretical Research, 15(2), 127-130. DOI: 10.1002/ptr.687

43. Mirghani, M. E., Liyana, Y. \& Parveen J. (2012). Bioactivity analysis of lemongrass (Cymbopogan citratus) essential oil. International Food Research Journal, 19, 569-575.

44. Misiak, M. \& Lodyga-Chruscinska, E. (2010). Interactions of flavonoids with transition metal ions. Pharmaceuticals, 9(11), 39-42.

https://www.researchgate.net/publication/285975044_Interactions_of_flavonoids_with_transition_metal ions

45. Nagavani, V., Madhavi, Y.D., Bhaskar Rao, P., Koteswara, R. \& Raghava RT. (2014) Free radical scavenging activity \& qualitative analysis of polyphenols by RP-HPLC in the flowers of Couroupitaguianensisabul Electronic. Journal of Environmental, Agricultural \& Food Chemistry, 9(9), 1471-1484

46. Oladeji, O.S., Adelowo, F.E., Ayodele, D.T., Odelade, K.A. (2019). Phytochemistry \& pharmacological activities of Cymbopogon citratus: A review. Scientific African, 6. https://doi.org/10.1016/j.sciaf.2019.e00137

47. Oladeji, O.S., Odelade, K.A \& Oloke, J.K. (2020) Phytochemical screening and antimicrobial investigation of Moringa oleifera leaf extracts, African Journal of Science, Technology, Innovation and Development, 12(1), 79-84. DOI: 10.1080/20421338.2019.1589082.

48. Olaiya, Charles \& Ojebode, Mojisola \& Karigidi, Kayode \& Efferth, Thomas. (2016). Antioxidant and Antibacterial Activities of the Essential Oils of Cymbopogon citratus and Citrus sinensis. European Journal of Medicinal Plants. 16(1). DOI: 10.9734/EJMP/2016/28176.

49. Olivero- Verbel, J., Nerio, L.S. \& Stashenko, E.E. (2010). Bioactivity against Tribolium castaneum Herbst (Coleoptera, Tenebrionidae) of Cymbopogon citratus \& Eucalyptus citriodora essential oils grown in Colombia. Pest Management Science, 66(6), 664-668. DOI: 10.1002/ps.1927

50. Olorunnisola, K., Asiyanbi-Hammed, T., Hammed, A., Simsek, S. (2014). Biological properties of lemongrass: An overview. International Food Research Journal, 21(2), 455-462. http://www.ifrj.upm.edu.my/21\%20(02)\%202014/4\%20IFRJ\%2021\%20(02)\%202014\%20043.pdf

51. Quettier, D.C., Gressier, B., Vasseur, J., Dine, T., Brunet, C., Luyckx, M.C., Cayin, J.C., Bailleul, F. \& Trotin, F. (2000). Phenolic compounds \& antioxidant activities of buckwheat (Fagopyrum esculentum Moench) hulls \& flour. Journal Ethnopharmacology, 72(1-2), 35-42. DOI: 10.1016/s0378$\underline{\text { 8741(00)00196-3 }}$

52. Quintans-Júnior, L.J., Guimarães, A.G., Santana, M.T., Araújo, B.E.S., Moreira, F.V., Bonjardim, L.R., Araújo, A.A.S., Siqueira, J.S., Antoniolli, A.R., Botelho, M.A., Almeida, J.R.G.S. \& Santos, M.R.V. (2011). Citral reduces nociceptive \& inflammatory response in rodents. Brazilian Journal of Pharmacognosy, 21, 497-502. http://dx.doi.org/10.1590/S0102-695X2011005000065

53. Ranitha, M., Abdurrahman, H., Suleiman, Z., Nour, A. \& Thana Raj, S. (2014). Comparative study of lemongrass (Cymbopogon citratus) essential oil extracted by microwave-assisted hydrodistillation (MAHD) \& conventional hydrodistillation (HD) method. International Journal Chemical Engineering \& Application, 5 (2), 104-108. DOI: http://dx.doi.org/10.7763/IJCEA.2014.V5.360

54. Salaria, D., Rajan Rolta, Nitin Sharma, Kamal Dev, Anuradha Sourirajan, Vikas Kumar (2020). In silico \& In vitro evaluation of the anti-inflammatory \& antioxidant potential of Cymbopogon citratus from North-western Himalayas. BioRXiv. Doi: https,//doi.org/10.1101/2020.05.31.124982

55. Saleh, M.A., Clark, S., Woodard, B., \& Deolu-Sobogun, S.A. (2010). Antioxidant \& free radical scavenging activities of essential oils. Ethnobiological Diseases, 20(1), 78-82. https://pubmed.ncbi.nlm.nih.gov/20521390/

56. Samoisy, A.K. \& Mahomoodally, M.F. (2015). Ethnopharmacological analysis of medicinal plants used against non-communicable diseases in Rodrigues Island, Indian Ocean. Journal of Ethnopharmacology, 173, 20-38. https://doi.org/10.1016/j.jep.2015.06.036

57. Sasidharan, S., Chen, Y., Saravanan, D., Sundram, K.M., Yoga, L. L. (2011). Extraction, isolation and characterization of bioactive compounds from plants' extracts. African Journal of Traditional, Complementary, and Alternative Medicines, 8(1),1-10. DOI: 10.1625/jcam.8.1.

58. Sete da Cruz, R.M., Alberton, O., Milena da Silva, L., Sete da Cruz, G.L. Gasparotto-Junior, A., Cardozo-Filho, L., Hulse de Souza, S.G. (2020). Phytochemistry of Cymbopogon citratus (D.C.) Stapf inoculated with arbuscular mycorrhizal fungi and plant growth-promoting bacteria. Industrial Crops and Products, 149, https://doi.org/10.1016/j.indcrop.2020.112340. 
59. Sharifi-Rad M., Anil Kumar Nanjangud V., Zucca Paolo, Varoni Elena Maria, Dini Luciana, Panzarini Elisa, Rajkovic Jovana, Tsouh Fokou Patrick Valere, Azzini Elena, Peluso Ilaria, Prakash Mishra Abhay, Nigam Manisha, El Rayess Youssef, Beyrouthy Marc El, Polito Letizia, Iriti Marcello, Martins Natália, Martorell Miquel, Docea Anca Oana, Setzer William N., Calina Daniela, Cho William C., Sharifi-Rad Javad. (2020). Lifestyle, Oxidative Stress, \& Antioxidants, Back \& Forth in the Pathophysiology of Chronic Diseases. Frontiers in Physiology, 11(694) DOI $=10.3389 /$ fphys .2020 .00694 .

60. Shruti, A. (2015). Lemongrass. International Journal of Pharmaceutical Sciences Review \& Research, 35(2), 162-167.

61. Tajidin, N.E., Ahmad, S.H., Rosenani, A.B., Azimah, H., Munirah. M. (2015). Chemical composition \& citral content in lemongrass (Cymbopogon citratus) essential oil at three maturity stages. African Journal of Biotechnology. 11 (11), 2685-2693

62. Tayupanta, M.T., Noriega, P., Cornejo, J., Pardo, M. (2016). Biological activity of Cymbopogon citratus (DC) Stapf and its potential cosmetic activities. International Journal of Phytocosmetics and Natural Ingredients. DOI: 10. 15171/ijpni.2016.07.

63. Tungmunnithum, D.; Thongboonyou, A.; Pholboon, A.; Yangsabai, A. (2018). Flavonoids and other phenolic compounds from medicinal plants for pharmaceutical and medical aspects: An overview. Medicines , 5, (93). https://doi.org/10.3390/medicines5030093

64. Tzanova, M., Atanasov, V., Yaneva, Z., Ivanova, D., Dinev, T. (2020). Selectivity of current extraction techniques for flavonoids from plant materials. Processes, 8 , 1222. https://doi.org/10.3390/pr8101222

65. Unuigbe, C., Enahoro, J., Erharuyi, O., Okeri, H.A. (2019). Phytochemical analysis and antioxidant evaluation of lemongrass (Cymbopogon citratus DC.) Stapf leaves. Journal of Applied Sciences and Environmental Management, 23(223). DOI: 10.4314/jasem.v23i2.4

66. Wang, L. \& Weller, C. L. (2006). Recent advances in extraction of nutraceuticals from plants. Trends in Food Science \& Technology, 17(6), 300-312. https://doi.org/10.1016/j.tifs.2005.12.004

67. Zaki, E., Aziz, N., Helmy, I., Maguid, N. (2018). Antioxidant \& antimicrobial effects of lemongrass (Cymbopogon citratus) oil on the quality characteristics of camel burger "camburger" under refrigerated storage. International Journal of Current Microbiology \& Applied Sciences, 7, 3623-3631. DIO: 10.20546/ijcmas.2018.703.418.

68. Zhang, Y.J., Gan, R.Y., Li, S., Zhou, Y., Li, A.N., Xu, D.P., Li, H.B. (2015). Antioxidant Phytochemicals for the Prevention \& Treatment of Chronic Diseases. Molecules, 12, 21-138. DOI: $10.3390 /$ molecules201219753 